\title{
Examination of Comfort Temperature in the Traditional and Modern Building of Warm Humid Region
}

\section{R. Shanthi Priya}

\begin{abstract}
A Questionnaire survey to understand the Thermal Comfort of the inhabitants was carried out in the traditional and modern residential buildings in the coastal region of Nagappattinam during various seasons. The list of Questionnaire was prepared based on the Literature studies from Thermal Comfort Survey - ASHRAE 55 standards to comprehend the effect of diverse Climatic factors such as temperature, humidity, air flow and overall thermal comfort factors in the evaluation of thermal comfort in traditional and modern residential buildings. The findings of this study were based on the collection of answers from the survey. The findings of the survey are compared with the technical investigations which is included at the end of this paper. These findings reveal that people living in the traditional buildings of the coastal belts of Nagapattinam are well modified to the harsh environment of traditional houses than modern houses.
\end{abstract}

Keywords - Thermal Comfort Survey, Comfort Temperature, Comfort Models

\section{INTRODUCTION}

The Questionnaire survey was carried out to understand the Environmental performance of typical vernacular dwellings and Modern buildings in the coastal belts of Tamil Nadu. Solar Passive features in traditional buildings and Modern buildings are described in Table-2. The survey report comprises of detailed Questionnaire survey of 50 vernacular and Modern houses (Table-3) and the values of Experimental Investigation and TSV of 200 residents on ASHRAE thermal sensation scale was recorded. Through this survey, the author has assessed the Environmental performance of these residences in varied seasons. The comfort conditions of the inhabitants living in the traditional typologies were studied through questionnaire, comfort temperature and neutral temperature was also calculated by thermal comfort models (Singh et al 2010). Recent studies on traditional buildings exposed that the findings got from the field measurements are commonly acknowledged to envisage the comfort temperature of traditional and Modern buildings. The comfort temperature range involves various Climatic parameters, adjustment of human being from harsh weather, sensitivity and expectations. So, in this survey both objective and personal measurements were organized concurrently during the investigation.

Revised Manuscript Received on December 05, 2019.

* Correspondence Author

R.Shanthi Priya*, Kalasalingam School of Architecture, shanthipriya@klu.ac.in

\section{THE ASHRAE SCALE}

The ASHRAE scale is an universal thermal scale developed by ASHRAE 55 standard which signifies Thermal Environmental Conditions for Human Occupancy (Figure-

\begin{tabular}{|c|c|c|c|c|c|c|}
\hline cold & cool & $\begin{array}{c}\text { Slightly } \\
\text { cool }\end{array}$ & Neutral & $\begin{array}{c}\text { Slightly } \\
\text { warm }\end{array}$ & Warm & Hot \\
\hline-3 & -2 & -1 & 0 & +1 & +2 & +3 \\
\hline
\end{tabular}

1).

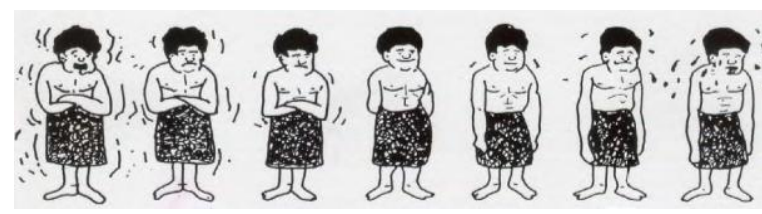

Figure -1 ASHRAE thermal comfort model

Source: ASHRAE Standard 55P, “Thermal Environmental Conditions for Human Occupancy”.

\section{INVESTIGATION METHODOLOGY}

The investigation followed a comparable prototype of questionnaires performed by Wong \& Khoo (2003), Wong et al (2002) in Singapore, Sadhan Mahapatra (2010), Abel Tablada (2005), Henry Feriadi (2004) in Indonesia. These Literature reviews were chosen for the valid comparison of the Environmental setting and for the coincidence of objectives. The questionnaire consisted of three sections. Private data, Environmental parameters and their opinion about overcoming the uncomfortable situation was also asked from the occupants of traditional and Modern dwellings. In the private data, occupants were asked about feeling of temperature by subjects depends on many aspects like age, sex, weight, height, clothes, occupation etc. The occupants of the traditional residences voted on ASHRAE 7 point thermal sensation scale by filling up the questions in the format. (Table-1). Table -3 and 4 shows the number of occupants interviewed during various seasons in varied typologies.

A set of questions were also given to ease the observational study on the frequent behavioral adjustment by the inhabitants and the responses were in the form of five-scale frequency of actions (Figure-1). The occupants were requested to estimate how frequently in a day they take the diverse flexible measures 
planned. Before the respondents replied the opinion poll, they were requested to be seated and settle down for about 30 minutes when the reviewer enlightened the intention of the survey and the process to update opinion poll formats. (Table-4). The Questionnaire was prepared in the regional language Tamil as per ASHRAE Format.

Table -2 Solar passive features in the traditional and Modern houses of Warm humid zone)

\begin{tabular}{|c|c|c|}
\hline & Wind catcher house & $\begin{array}{l}\text { Modern } \\
\text { House }\end{array}$ \\
\hline Bio climatic Zone & Warm Humid & Warm Humid \\
\hline $\begin{array}{l}\text { Built } \\
\text { (sq.m) }\end{array} \quad-$ up area & 110 & 120 \\
\hline $\begin{array}{l}\text { Building Envelope } \\
\text { (walls) }\end{array}$ & $\begin{array}{l}\text { mud, Brick }(0.2 \mathrm{~m}) \text { lime mortar, } \\
\text { timber, bamboo }\end{array}$ & Brick wall \\
\hline Roofing & thatch roofing, country roof tiles & $\mathrm{RCC}$ roof \\
\hline Ventilation & $\begin{array}{l}\begin{array}{l}\text { Doors, windows and } \\
\text { catchers }\end{array} \\
\text { cand } \\
\end{array}$ & $\begin{array}{l}\text { Doors and } \\
\text { Windows }\end{array}$ \\
\hline $\begin{array}{l}\text { Building layout and } \\
\text { Orientation }\end{array}$ & Open layout ,East west orientation & $\begin{array}{l}\text { East and } \\
\text { West } \\
\text { orientation } \\
\end{array}$ \\
\hline $\begin{array}{l}\text { Solar } \\
\text { elements }\end{array}$ & $\begin{array}{l}\text { Thick external cavity walls, } \\
\text { verandas, sloping } \\
\begin{array}{ll}\text { courtyards, wind catchers, doors } \\
\text { and windows }\end{array} \\
\end{array}$ & Nil \\
\hline
\end{tabular}

Table -3 Sampling distribution in the study area of coastal region

\begin{tabular}{|c|c|c|}
\hline & \multicolumn{2}{|c|}{ Study area of Coastal region, Tamil Nadu } \\
\hline $\begin{array}{c}\text { Number of } \\
\text { questions }\end{array}$ & Summer season & Winter Season \\
\hline $\begin{array}{c}\text { Number of } \\
\text { Residences }\end{array}$ & 200 & 200 \\
\hline $\begin{array}{c}\text { Survey date } \\
\text { Time }\end{array}$ & 50 & 50 \\
\hline $5^{\text {th }}$ May $-5^{\text {th }}$ June 2016 & $\begin{array}{c}8^{\text {th }} \text { Nov. }-10^{\text {th }} \\
\text { Dec } 2016\end{array}$ \\
\hline (no. of questions) & Morning -10 & $\begin{array}{c}\text { Morning }-10 \\
\text { Afternoon }-25 \\
\text { Evening }-15\end{array}$ \\
\hline
\end{tabular}

Table -4 personal parameters

\begin{tabular}{|c|c|c|c|}
\hline & Personal parameters & \multicolumn{2}{|c|}{ India } \\
\hline & & Winter & Summer \\
\hline 1. & Clo value & 0.4 & 0.3 \\
\hline \multirow{2}{*}{2.} & Met. rate & 1 & 1 \\
\hline 3. & Height (cm) & 158 & 160 \\
\hline \multirow{2}{*}{4.} & Weight (kg) & 60 & \\
\hline 5. & Gender & & \\
\hline \multirow{2}{*}{5} & Male & 120 & 120 \\
\cline { 2 - 4 } & Female & 80 & 80 \\
\hline \multirow{2}{*}{6.} & Age (years) & & 100 \\
\hline & $<20$ & 10 & 100 \\
\cline { 2 - 4 } & $21-30$ & & \\
\hline
\end{tabular}

\begin{tabular}{|c|c|c|c|}
\hline $31-40$ & 50 & 50 \\
\cline { 2 - 4 } & $41-50$ & 40 & 40 \\
\cline { 2 - 4 } & $>50$ & & \\
\hline
\end{tabular}

4. Assessment of Neutral Temperature and Comfort Temperature

The Thermal comfort votes were traced on ASHRAE 7 point sensation scale (Table-1). In X-axis, Operative air temperatures and in $\mathrm{Y}$ - axis mean thermal sensation vote as per ASHRAE Thermal sensation scales are plotted. Neutral temperature is defined as the temperature at which a person feels thermally comfortable at fixed variables like environmental parameters, clothing and activity level (Singh et al., 2009) and it is calculated by using regressions. Table- 5 represents the Indoor and Outdoor temperature measured using Hobo data loggers at the selected traditional and Modern House and the results were published in the journal.(shanthipriya et. al). In Table -7 , the comfort temperature is evaluated by Humphreys and Auxiliems Models. In Table -6, Comfort temperature range is calculated for all the seasons which also consist of Temperature swings for all months and the Thermal Lag calculated from the data obtained from meteorological station. Different age group of the occupants casted their vote based on their state of emotions and actions. Based on this fact, it was observed that at similar temperature, occupants of varied age group, and gender have varied thermal sensation or else similar sensation at varied temperature.

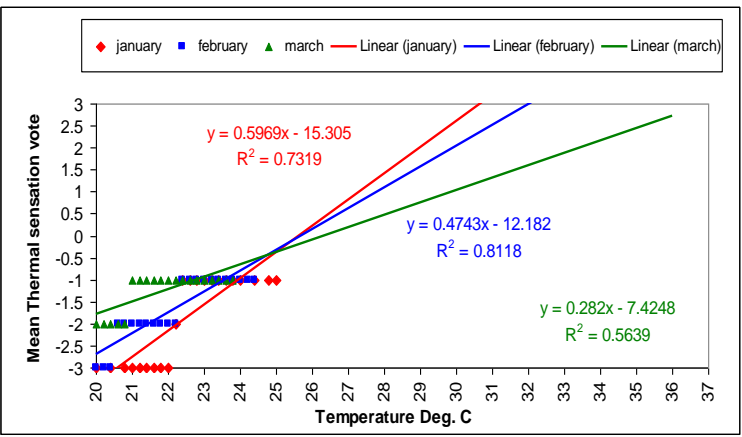

Figure-2(a) Regression on TSV on indoor operative temperature (January, February, March)

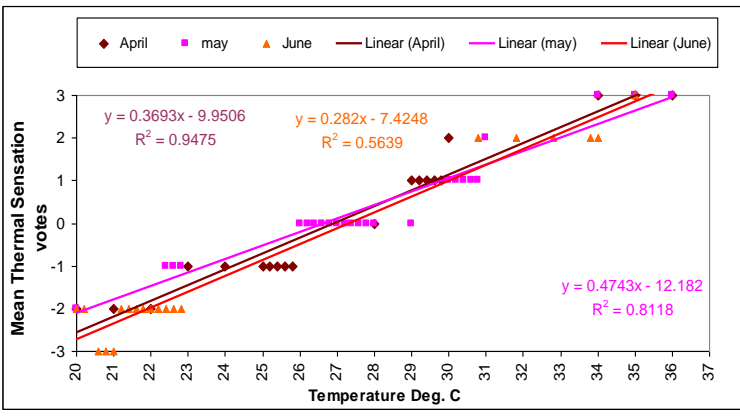

Figure -2(b) Regression on TSV on indoor operative temperature (April, May, June) 


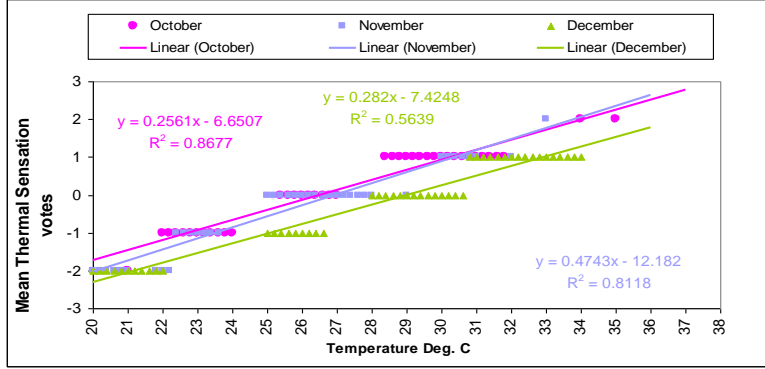

Figure-2(c) Regression on TSV on indoor operative temperature (October, November, December)

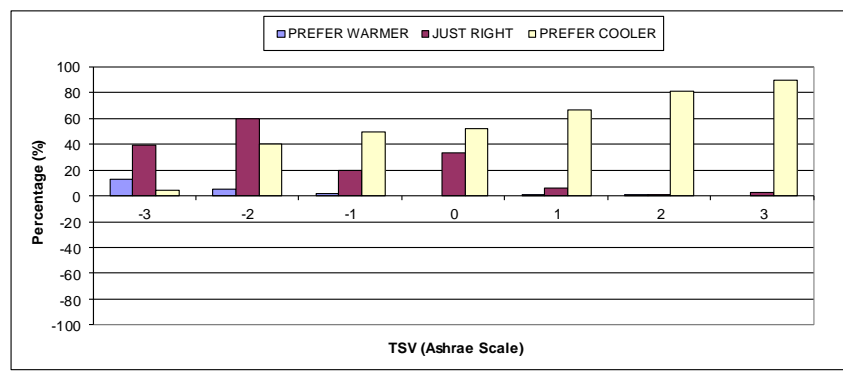

Figure-3 Thermal sensation votes (ASHRAE scale)

In warm humid climatic zones of coastal Tamil Nadu, the respondents also voted their preferences (prefer warmer, Just right, Prefer Cooler). From the above chart it was found that more people preferred cooler environment than warmer environment. More people preferred cooler environment though they have voted for -1 (slightly cool), 0 (Neutral) and +1 (slightly warm) in ASHRAE 7 point scale (Figure-3).

\section{Questionnaire Survey - Comfort Level - Winter}

From Fig.4, it is found that $68 \%$ of the residents of traditional typologies preferred that their houses are very comfortable in winter and the left over $32 \%$ of the residents opted for comfortable, $5 \%$ opted for slightly uncomfortable, $3 \%$ opted for uncomfortable, $2 \%$ opted for very uncomfortable. Only $20 \%$ of the residents of modern typology stated that their buildings are very comfortable in winter and left over $80 \%, 15 \%$ of the residents opted for comfortable, $20 \%$ of the residents opted for slightly uncomfortable, $25 \%$ residents opted for uncomfortable, $20 \%$ of the residents opted for very uncomfortable during winter.

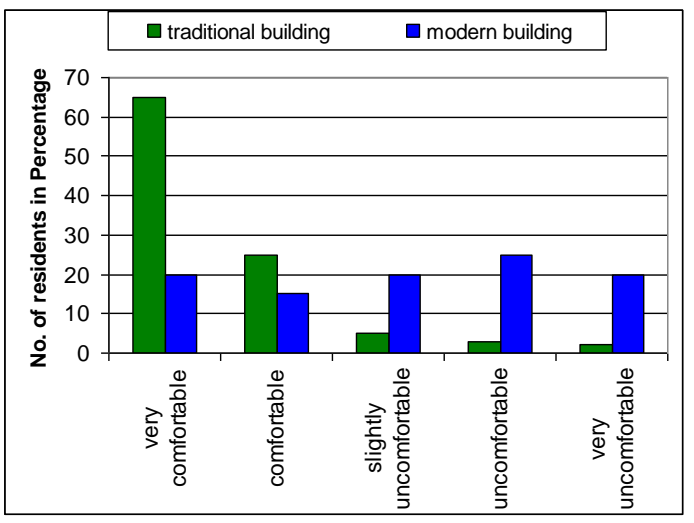

Figure -4 Questionnaire -thermal comfort - winter season

\section{Questionnaire Survey - Comfort Levels -} summer

In traditional typology $64 \%$ of the residents felt very comfortable during harsh weather( summer) and the left over $36 \%$ of the residents selected for comfortable, slightly uncomfortable, uncomfortable, very uncomfortable with an allocation of $20 \%, 4 \%, 2 \%$ and $1 \%$ correspondingly. In Modern typology not even a single person preferred for comfortable and around $70 \%$ of the inhabitants found that their buildings were uncomfortable. Figure -5

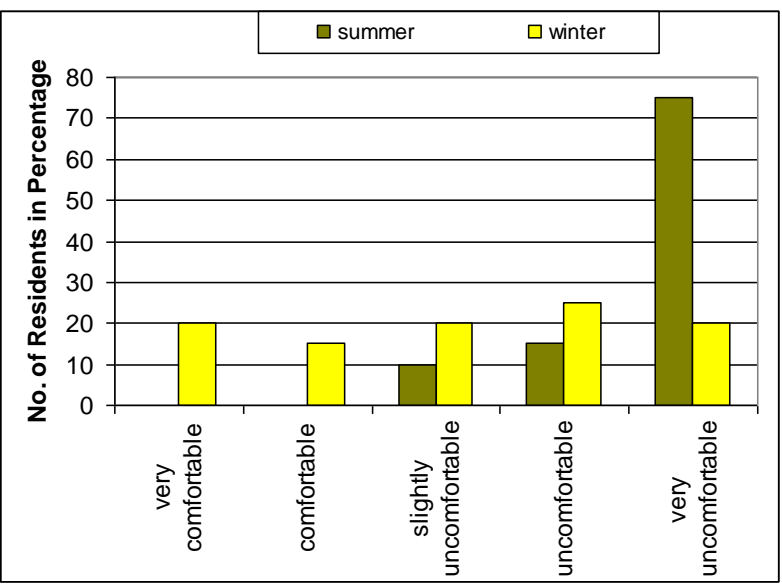

Figure -5: questionnaire on comfort -Various Seasons in Modern Buildings.

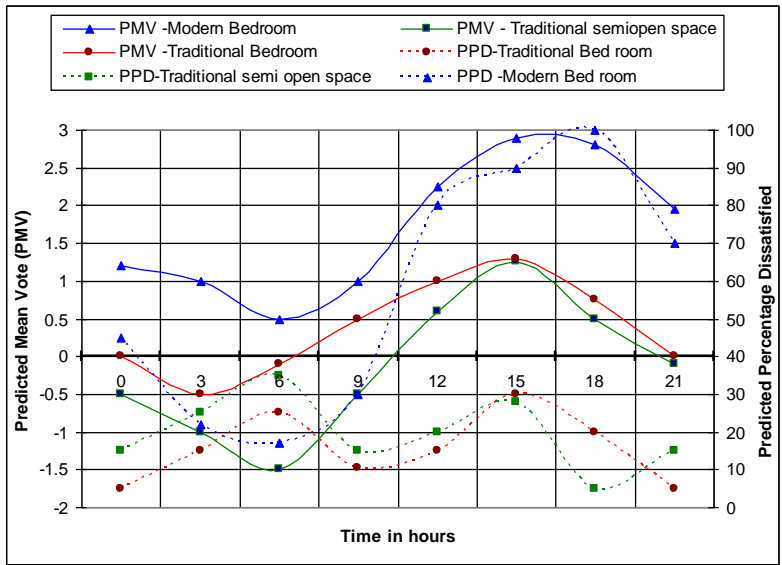

Figure-6 PMV and PPD vs. Time

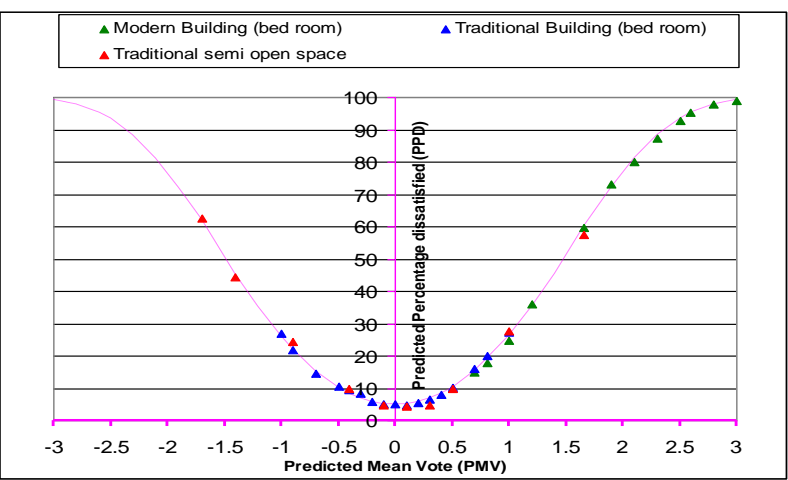

Figure-7 PMV vs. PPD 


\section{Assessment of Thermal Comfort in Traditional and Modern typologies using Fangers Model}

Thermal comfort of a person is determined by certain Environmental factors such as AT, MRT, RH, air movement, type of clothing and action. Most of the occupants feel comfortable in their clothing levels and activity ranges under given Environmental conditions. PMV and PPD based on Fanger's comfort theory was carried out for both the buildings. In both the buildings people wearing Normal clothing- their clo value and performing normal activities- metabolic rate were assumed. From Figures- 6 and 7 , it was found apparent that the traditional typology is relaxing for the most part of the time in summer compared to the modern one. The assessment using PMV -PPD study, proves that the traditional typologies are comfortable during summer.

Table-7 Calculation of comfort and neutral temperatures

\begin{tabular}{|c|c|c|c|c|c|}
\hline Place & Months & $\begin{array}{l}\text { (Humphreys) } \\
\mathrm{CT}^{\circ} \mathrm{C}\end{array}$ & $\begin{array}{l}\text { (Auxiliems) } \\
\mathrm{CT}^{\circ} \mathrm{C}\end{array}$ & $\begin{array}{l}\text { Neut. } \\
\text { Temp. } \\
{ }^{\circ} \mathrm{C} \\
\text { (regression } \\
\text { analysis) }\end{array}$ & $\begin{array}{l}\text { Neut. } \\
\text { Temp. }{ }^{\circ} \mathrm{C} \\
\text { (survey) }\end{array}$ \\
\hline \multirow{6}{*}{$\begin{array}{c}\text { Traditional } \\
\text { building in } \\
\text { the study } \\
\text { area of } \\
\text { Coastal } \\
\text { region in } \\
\text { Tamil } \\
\text { Nadu }\end{array}$} & Jan. & 25.8 & 25.9 & 25.2 & 25.8 \\
\hline & April & 29.2 & 27.9 & 27.5 & 27.2 \\
\hline & May & 29.8 & 29.5 & 27.8 & 28.4 \\
\hline & June & 29.2 & 30.0 & 28.5 & 29.0 \\
\hline & November & 26.8 & 26.8 & 26.5 & 26.1 \\
\hline & December & 26.9 & 26.8 & 26.5 & 25.3 \\
\hline \multirow{6}{*}{$\begin{array}{l}\text { Modern } \\
\text { building in } \\
\text { the study } \\
\text { area of } \\
\text { Coastal } \\
\text { region in } \\
\text { Tamil } \\
\text { Nadu }\end{array}$} & January & 30.8 & 29.9 & 28.2 & 28.7 \\
\hline & April & 33.2 & 27.9 & 32.9 & 33.9 \\
\hline & May & 34.8 & 35.0 & 33.8 & 34.2 \\
\hline & June & 34.2 & 34.9 & 32.5 & 33.2 \\
\hline & November & 30.8 & 29.8 & 29.5 & 28.1 \\
\hline & December & 29.6 & 29.8 & 28.4 & 29.3 \\
\hline
\end{tabular}

Adaptive behavior model is excellent verification method from the occupants to understand the users original occupancy level.

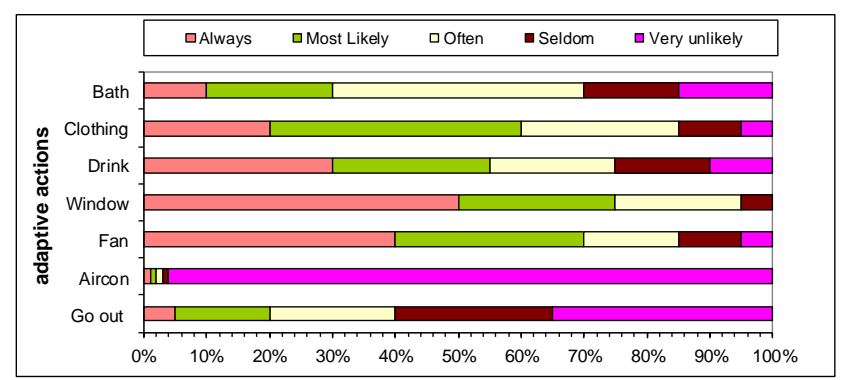

Figure-8 Adaptive actions of the people

The above chart shows the $\%$ of adaptive activities of the inhabitants in the traditional typologies of coastal belts in Tamil Nadu. Around $60 \%$ of the people preferred to open the windows, $40 \%-50 \%$ of the people preferred to switch on the fan, $30 \%-40 \%$ of the people prefer to drink water, $20 \%$ $30 \%$ prefer to change their clothes, very less percentage $(<10 \%)$ prefer to take bath and switch on AC (less than $10 \%)$ to make them thermally comfortable (Figure-8). Reasonably many people liked to open windowpane and switch on fans in coastal region of Tamil Nadu signifies that wind movement in the interior of the residence is greatly favorable to overcome the humidity prevailing in the coastal regions.

\section{DISCUSSIONS}

This study on Thermal Comfort Survey showed that ASHRAE scales had predicted higher thermal comfort level in the traditional typologies of coastal region in Tamil Nadu. From the study, it is found that the results obtained from the adaptive models lie in harmony with the temperature recorded in the traditional buildings through experimental investigation during summer and winter months. The most important conclusion which can be drawn from this study is that other than $80 \%$ of the inhabitants stated that, their harsh thermal interior surroundings were tolerable, yet the TSV surpassed tolerable thermal conditions set by the ASHRAE standards. The neutral temperature and comfort range were acquire through linear regression analysis of TSV (Table-7). From the individual evaluation, it was recognized that the inhabitants admitted the thermal range beyond the ASHRAE comfort zone. This paper also discusses the resident's actions in utilizing the diverse ecological and individual control to make them relaxing from the harsh weather.

\section{CONCLUSIONS}

The Comfort Temperature prevailing in the traditional houses and Modern houses of coastal region was evaluated using various Thermal Comfort survey Models and it was found that the findings of the survey lies in harmony with the comfort temperature evaluated from experimentation methods. The results from the questionnaire survey also showed the preference of the inhabitants to become accustomed to the tropical humid existing surroundings by generating a better wind movement (rotating fans, opening the windows). It is apparent from the lessons that a appropriate material usage, spatial association, Building technique and Environmental strategies might fetch the much required relaxed thermal environment inside the typologies. These findings reveal that people living in the traditional typologies of the coastal region are well adapted to the harsh environment of traditional houses than modern houses. 
Table -5 - Indoor and Outdoor Temperature

\begin{tabular}{|l|l|l|l|l|l|l|}
\hline & \multicolumn{2}{|l|}{ Traditional House } & \multicolumn{3}{c|}{ Modern House } \\
\hline Months & $\begin{array}{l}\text { outside } \\
\text { ambient } \\
\text { Temp. } \\
\text { (a) }\end{array}$ & $\begin{array}{l}\text { Inside } \\
\text { Temp. } \\
-{ }^{\circ} \mathrm{C}\end{array}$ & $\begin{array}{l}\text { outside } \\
\text { ambient } \\
\text { Temp. } \\
-{ }^{\circ} \mathrm{C}(\mathrm{b})\end{array}$ & $\begin{array}{l}\text { Outside } \\
\text { ambient } \\
\text { temp. } \\
{ }^{\circ} \mathrm{C}(\mathrm{a})\end{array}$ & $\begin{array}{l}\text { Mean } \\
\text { inside } \\
\text { Temp } \\
{ }^{\circ} \mathrm{C}\end{array}$ & $\begin{array}{l}\text { outside } \\
\text { ambient } \\
\text { temp } \\
{ }^{\circ} \mathrm{C}(\mathrm{b})\end{array}$ \\
\hline Jan. & 35 & 26.5 & 34.2 & 35.1 & 32.3 & 33.8 \\
\hline April & 37.9 & 30.1 & 38.2 & 37.9 & 35.4 & 38 \\
\hline May & 39.3 & 29.3 & 38.2 & 39.3 & 34.2 & 38.2 \\
\hline June & 38.1 & 31.2 & 38.5 & 38.1 & 34.9 & 37.5 \\
\hline November & 34.2 & 25.4 & 33.8 & 34.2 & 31.1 & 33 \\
\hline December & 33.4 & 24.1 & 34.1 & 33.4 & 30.3 & 32.9 \\
\hline
\end{tabular}

b

Site Measurement - Data Logger

a Weather Station

Table -6 Comfort temperature range based on comfort

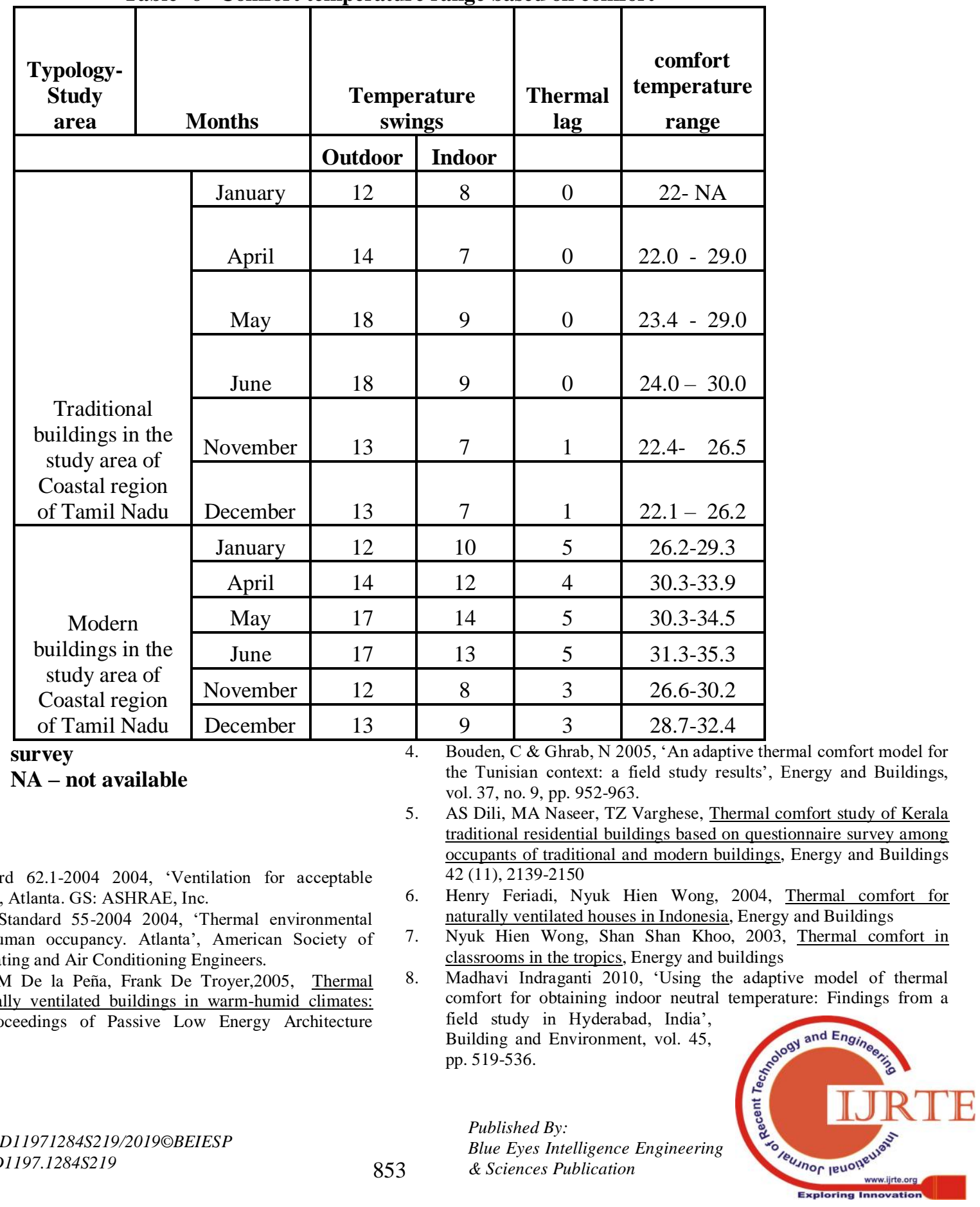

\section{REFERENCES:}

1. ASHRAE standard 62.1-2004 2004, 'Ventilation for acceptable indoor air quality', Atlanta. GS: ASHRAE, Inc.

2. ANSI/ASHRAE Standard 55-2004 2004, 'Thermal environmental conditions for human occupancy. Atlanta', American Society of Heating, Refrigerating and Air Conditioning Engineers.

3. Abel Tablada, AM De la Peña, Frank De Troyer,2005, Therma comfort of naturally ventilated buildings in warm-humid climates: field survey, Proceedings of Passive Low Energy Architecture (PLEA), Beiru 
9. Shanthi Priya, R, Sundarraja, MC \& Radhakrishnan, S 2012, 'Evaluation of traditional architecture in the coastal region of Nagapattinum using Mahoney tables', Journal of Applied Sciences Research, INSInet Publications. vol. 8, no.1, pp. 582-588. (Impact Factor: 0.240).

10. Shanthi Priya, R, Sundarraja, MC, Radhakrishnan, S \& Vijayalakshmi, S 2012, 'Solar passive techniques in the vernacular buildings of coastal regions in Nagapattinum, Tamil Nadu-India - a qualitative and quantitative analysis', Energy and Buildings, Elsevier Publications. vol. 49, pp.50-61. (Impact factor: 2.386, Citations-1).

11. Shanthi Priya, R, Sundarraja, MC \& Radhakrishnan, S 2012, 'Comparing the thermal performance of traditional and modern building in the coastal region of Nagappattinam, Tamil Nadu', Indian Journal of Traditional Knowledge, NISCAIR Publications, vol.11, no. 3, pp. 542-547. (Impact factor: 0.399, Citations-1).

12. Shanthi Priya. R, Nirmal Raj, AR, Sundarraja, MC \& Jinu Louishidha Kitchley 2011, 'Climate sensitive Architecture of tribal vernacular settlements in hilly regions of mattupatti village, idukki district, kerala, India', ABACUS, vol. 6, no. 2, pp. 1-7, Monsoon. (Impact factor: 0.080).

13. Shanthi Priya, R, Sundarraja, MC \& Radhakrishnan, S 2012 , 'Experimental study on the thermal performance of a traditional house with one sided wind catcher during summer and winter', Energy Efficiency, Springer Publications. vol. 5, no. 4, pp. 483-496. (Impact factor: 1.085).

14. Singh, MK, Mahapatra, S \& Atreya, SK 2009, 'Bioclimatism and vernacular architecture of North-east India', Building and Environment, vol. 44, pp. 878-888.

15. Singh, MK, Mahapatra, S \& Atreya, SK 2010, 'Thermal performance study and evaluation of comfort temperatures in vernacular buildings of North-East India', Building and Environment, vol. 45, pp. 320-329.

16. Singh, MK, Mahapatra, S \& Atreya, SK 2007, 'Development of bio-climatic zones in North East India', Energy Buildings, vol. 39 , no. 12 , pp.1250-1257.

17. NH Wong, H Feriadi, PY Lim, KW Tham, C Sekhar, KW Cheong, 2002, Thermal comfort evaluation of naturally ventilated public housing in Singapore, Building and Environment.

18. Yao, R, Li, B \& Liu, J 2009, "A theoretical adaptive model of thermal comfort. Adaptive predicted Mean vote (a PMV)', Build Environ, vol. 44, no. 10, pp. 2089-2096.

19. baadalsg.inflibnet.ac.in

20. Ibrahim Hussein, M. Hazrin A. Rahman, Tina Maria. "Field studies on thermal comfort of air-conditioned and non air-conditioned buildings in Malaysia", 2009 3rd International Conference on Energy and Environment (ICEE), 2009

21. Singh, M.K.. "Thermal performance study and evaluation of comfort temperatures in vernacular

22. buildings of North-East India", Building and Environmen

23. "Sustainable Houses and Living in the Hot-Humid Climates of Asia", Springer Nature, 2018

24. Manoj Kumar Singh, Sadhan Mahapatra, Jacques Teller "Development of thermal comfort models for various climatic zones of North-East India", Sustainable Cities and Society, 2015

25. Deb, C. "Evaluation of thermal comfort in a rail terminal location in India", Building and Environment, 2010-11

26. Sushil B. Bajracharya. "The Thermal Performance of Traditional Residential Buildings in Kathmandu Valley", Journal of the Institute of Engineering, 2014

27. Shanthi Priya, Anna University, Ph.D report- 2013 